\title{
Penanganan Ties Event dalam Regresi Cox Proportional Hazard Menggunakan Metode Breslow (Kasus: Pasien Rawat Inap DBD di RSAL Jala Ammari Makassar)
}

\author{
Herawati Hafid*, M.Nadjib Bustan, Muhammad Kasim Aidid \\ Program Studi Statistika, Fakultas Matematika dan Ilmu Pengetahuan Alam, Universitas Negeri Makassar, Indonesia
}

Keywords: Survival Analysis, Cox PH Regression, Ties Event, Breslow Method, Dengue Hemorrhagic Fever (DHF).

\begin{abstract}
:
Survival analysis is a statistical procedure that is used to analyze data where the variables considered are the time until the occurrence of an event. Time can be expressed in days, weeks, months and years. One of the objectives of survival analysis is to find out the relationship between the time of occurrence of independent variables measured at the time of the study. The method often used in survival analysis, especially health data, is Cox Proportional Hazard (PH) Regression because its distribution does not depend on the assumption of the time of the event. In a data such as data on patients with Dengue Hemorrhagic Fever (DHF) data, there were ties event data that influenced the formation of risk sets in the cox model parameter estimation section, in the case of ties event modifications were made to the partial likelihood for know the factors that influence the recovery rate of patients with DHF. As for the results of the analysis, the factors that most influence the recovery rate of leucocyte dengue fever with $p$-value $=0,097<\alpha=0,05$ and the hazard ratio of 1.1024 and the second factor is the hematocrit with $p$-value $=0,0141<\alpha=0,05$ and the hazard ratio valueamounting to 1,595 .
\end{abstract}

\section{Pendahuluan}

Analisis survival merupakan prosedur statistika yang digunakan untuk menganalisis data dimana peubah yang diperhatikan adalah waktu sampai terjadinya suatu event. Dalam analisis survival terdapat peubah waktu sebagai uji hidup (survival time), karena menunjukkan waktu itu seseorang telah bertahan (survived) selama periode tertentu. Demikian pula secara khusus menunjuk kejadian sebagai suatu kegagalan, karena kejadian yang menjadi perhatian biasanya kematian, timbulnya penyakit atau beberapa kejadian lainnya (Kleinbaum \& Klein, 2005).

Analisis survival terbagi atas dua yaitu parametrik dan nonparametrik. Non parametrik digunakan apabila suatu data tidak mengikuti suatu distribusi tertentu begitu pula sebaliknya untuk yang parametrik. Seperti yang telah diketahui sebelumnya bahwa analisis survival sering digunakan dalam bidang kesehatan dan salah satu metode yang paling lumrah digunakan dibandingkan metode lainnya adalah metode Cox Proportional Hazard. Metode ini tidak tergantung pada asumsi distribusi waktu kejadian. Waktu kejadian atau waktu survival, dalam analisis survival terbagi menjadi 2 macam yaitu waktu kejadian tanpa ties dan waktu kejadian dengan ties.

Ties atau kejadian bersama adalah keadaan dimana terdapat dua individu atau lebih yang mengalami kejadian pada waktu secara bersamaan. Peneliti sering menghindari adanya data yang mengalami ties karena ties mengakibatkan

\footnotetext{
* Corresponding author.

E-mail address: herawatihafid@gmail.com
} 
permasalahan dalam membentuk partial likelihood yaitu saat menentukan anggota himpunan risikonya (Xin, 2011). Pendekatan untuk mengatasi kejadian bersama dalam analisis survival terdapat 3 metode, yaitu metode Efron, metode Breslow dan metode Exact (Breslow, 1974). Metode Breslow merupakan metode yang sangat sederhana sehingga sering digunakan dalam mengatasi kejadian bersama. Metode Breslow mengasumsikan bahwa ukuran dari himpunan risiko untuk kejadian bersama adalah sama. Kesederhanaan metode Breslow terdapat pada awal menganalisis karena tidak harus mengurutkan data atau kejadian mana yang terjadi terlebih dahulu seperti pada metode lainnya. Penelitian ini akan menggunakan model Cox Proportional Hazard dengan pendekatan Breslow untuk mengatasi kejadian bersama.

Pada kasus pasien penderita penyakit Demam Berdarah Dengue (DBD) sering didapati data yang mengalami kejadian bersama yakni mulai dari waktu pasien mengalami suatu penyakit secara bersamaan yang dimulai dari awal masuk rumah sakit sampai terjadi kejadian tertentu, seperti kematian, kesembuhan maupun kejadian khusus lainnya dalam waktu yang bersamaan. DBD adalah penyakit yang disebabkan oleh virus Dengue (Arbovirus) yang ditularkan kepada manusia melalui gigitan nyamuk Aedes aegypti dan penyakit ini masih menjadi masalah kesehatan bagi tenaga kesehatan khususnya, maupun masyarakat luas pada umumnya. Hal ini dikarenakan penyakit ini dapat menimbulkan wabah yang apabila penanganannya tidak tepat dapat mengakibatkan kematian.

Berdasarkan uraian diatas penulis ingin membahas model Cox Proportional Hazard untuk memodelkan faktor-faktor yang mempengaruhi laju kesembuhan pasien rawat inap penderita DBD dan mengatasi kejadian bersama (ties) dengan metode Breslow.

\section{Metode Penelitian}

Adapun Teknik analisis data adalah sebagai berikut :

(1) Melakukan analisis deskriptif terhadap peubah bebas dan terikat yang akan digunakan dalam penelitian ini ditentukan di awal penelitian.

(2) Melakukan Uji distribusi data

(3) Melakukan pengujian asumsi proportional hazard menggunakan uji global test.

(4) Pemodelan regresi cox PH.

a. Estimasi Parameter model Cox. Estimasi parameter dalam proses pembentukan model cox pada umumnya menggunakan maximum partial likelihood(MPLE) dalam memaksimalkan partial likelihoodnya yakni pada saat menentukan anggota himpunan risikonya.Pada estimasi digunakan pendekatan Breslow. Pendekatan ini banyak digunakan karena fungsi partial likelihoodnya sederhana dibandingkan metode lain.

b. Pengujian parameter. Pada model, dilakukan uji signifikansi parameter untuk mengetahui variabel-variabel yang berpengaruh signifikan dalam pembentukan model cox proportional hazard, yang meliputi uji bersamaan menggunakan metode log partial likelihood dan uji individu dengan uji Wald. Maka dilakukan pengujian setiap variable dengan uji wald.

(5) Penyusunan model cox pada kasus kejadian bersama (ties)

Setelah dilakukan seleksi berbagai uji maka akan diperoleh model terbaik, yang akan digunakan sebagai model terakhir cox proportional hazard.

(6) Menentukan Hazard rasio

Untuk mengetahui tingkat risiko (kecenderungan) yang dapat dilihat dari perbandingan antara individu dengan kondisi peubah bebas $\mathrm{X}$ pada kategori sukses dengan kategori gagal.

\section{Hasil dan Pembahasan}

\subsection{Analisis Deskriptif}

Analisis statistika deskriptif dari peubah penjelas mengenai jumlah presentase pasien penderita penyakit Demam Berdarah Dengue (DBD) berdasarkan jenis kelamin pasien dapat dilihat pada gambar 1. 


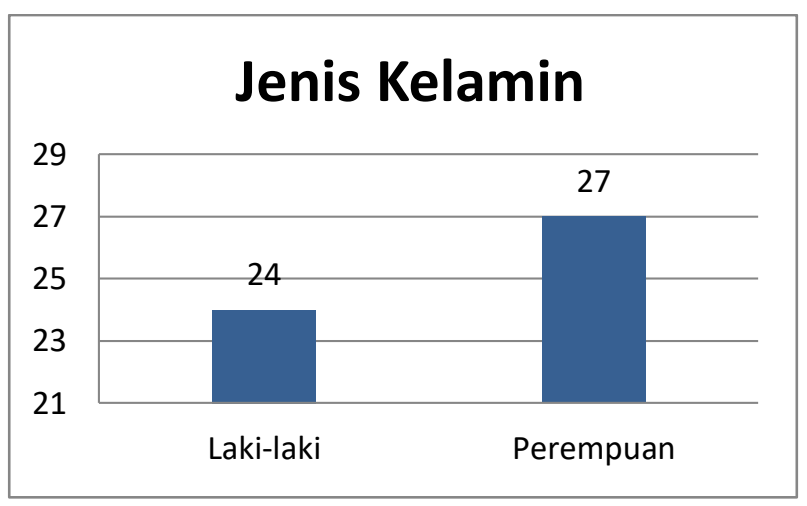

Gambar 1 Diagram batang pasien penderita DBD di RSAL Jala Ammari Makassar tahun 2016 berdasarkan jenis kelamin

Pada gambar 1 pasien dapat dilihat bahwa jenis kelamin perempuan lebih banyak dibandingkan dengan jenis kelamin laki-laki pasien penderita DBD yakni 27 orang perempuan atau sekitar 52,94 \% sedangkan laki-laki sebanyak 24 orang atau sekitar 47,05 \%. Hasil ini memperlihatkan bahwa selama periode Januari-Desember, pasien penderita penyakit Demam DBD di RSAL Jala Ammari Makassar lebih banyak yang berjenis kelamin perempuan.

Tabel 1 Analisis deskriptif terhadap 51 responden pasien DBD

\begin{tabular}{lllll}
\hline Peubah & Minimum & Maximum & Mean & Std. Deviasi \\
\hline Waktu (Hari) & 2,00 & 9,00 & 4,90 & 1,72 \\
Usia (Tahun) & 3,00 & 52,00 & 16,74 & 13,11 \\
Trombosit $(\mu l)$ & 11,0 & 320,0 & 114,61 & 68,24 \\
Leukosit $\left(\mathrm{mm}^{3}\right)$ & 1,1 & 17,3 & 6,33 & 3,58 \\
$\mathrm{Hb}(\mathrm{g} / \mathrm{dl})$ & 9,1 & 18,3 & 13,28 & 2,07 \\
Hematokrit $(\%)$ & 25,5 & 54,7 & 40,10 & 5,91 \\
Suhu Badan $\left({ }^{\circ} \mathrm{C}\right)$ & 36,0 & 39,8 & 37,56 & 0,99 \\
\hline
\end{tabular}

Sumber: Hasil analisis data sekunder 2018

Tabel 1 dapat dilihat bahwa pasien penderita DBD diberikan perawatan paling cepat 2 hari dan yang paling lama 9 hari, lama perawatan pasien penderita DBD memiliki rata-rata selama 5 hari. Selanjutnya untuk usia pasien penderita DBD usia terendah adalah 3 tahun dan usia tertinggi 52 tahun dengan rata-rata usia pasien penderita DBD adalah 16 tahun.

Pada hasil analisis tercatat bahwa jumlah trombosit yang terkecil pada pasien penderita penderita DBD adalah $11.000 / \mu l$ dan jumlah trombosit yang terbesar pada pasien penderita DBD adalah $320.000 / \mu l$, rata-rata jumlah trombosit pada pasien penderita DBD adalah $115.000 / \mu l$. Selanjutnya jumlah leukosit yang terkecil pada pasien penderita DBD adalah $1.100 / \mathrm{mm}^{3}$ dan jumlah leukosit yang terbesar pada pasien penderita DBD adalah $17.300 / \mathrm{mm}^{3}$, Rata-rata jumlah leukosit pada pasien penderita penyakit DBD adalah $6.330 / \mathrm{mm}^{3}$. Selanjutnya untuk hemoglobin yang terkecil pada pasien penderita DBD adalah 9,1 g/dl dan hemoglobin yang terbesar pada pasien penderita DBD adalah $18,28 \mathrm{~g} / \mathrm{dl}$. Selanjutnya kadar hematokrit yang terkecil pada pasien penderita DBD adalah $25,5 \%$ dan kadar hematokrit yang terbesar pada pasien penderita DBD adalah 54,7\% rata-rata kadar hematokrit pada pasien penderita DBD adalah 40,10\%. Dan untuk suhu badan yang terkecil pada pasien penderita DBD adalah $36^{\circ} \mathrm{C}$ dan suhu badan yang terbesar pada pasien penderita DBD adalah $39,8^{\circ} \mathrm{C}$ dengan Rata-rata suhu tubuh pada pasien penderita DBD adalah $37,56^{\circ} \mathrm{C}$. 


\subsubsection{Kejadian Bersama (ties event)}

Tabel 2 Jumlah ties event pada data

\begin{tabular}{ccc}
\hline Jumlah hari & Jumlah ties event & Keterangan \\
\hline 1 & 0 & Bukan ties \\
2 & 4 & Ties \\
3 & 10 & Ties \\
4 & 8 & Ties \\
5 & 11 & Ties \\
6 & 12 & Ties \\
7 & 3 & Ties \\
8 & 1 & Bukan ties \\
9 & 2 & Ties \\
Total & 51 & \\
\hline
\end{tabular}

Pada data pasien penderita penyakit DBD di RSAL Jala Ammari Makassar Tahun 2016 terdapat 51 data pasien dengan 49 kejadian bersama (ties event). Hal ini dapat dilihat dari tabel 4.2 yakni jumlah hari lama kesembuhan pasien DBD (Y). Jumlah keseluruhan dikurangi dengan jumlah yang bukan ties yakni sebesar 51-2 = 49 data yang mengalami ties.

\subsubsection{Pengujian Distribusi Data Pasien Penyakit DBD di RSAL Jala Ammari Makassar Tahun 2016}

Pengecekan distribusi data digunakan untuk mengetahui distribusi yang sesuai dengan data pasien rawat inap penyakit DBD, hasil output pada tabel 3.

Tabel 3 Hasil uji kecocokan distribusi pada data waktu survival

\begin{tabular}{cc}
\hline Distribusi & $\boldsymbol{p}$-value \\
\hline Exponential & $<0,001$ \\
Weibull & 0,001 \\
Gamma & 0,001 \\
Lognormal & 0,001 \\
\hline
\end{tabular}

Sumber: Hasil analisis data sekunder 2018

Berdasarkan Tabel 3 untuk data pasien penderita penyakit DBD, diperoleh bahwa nilai $p$-value menunjukkan data tidak mengikuti distribusi, karena data tidak mengikuti distribusi maka dapat dilanjutkan dengan model semiparametrik menggunakan regresi cox.

\subsubsection{Pengujian Asumsi Proportional Hazard (PH)}

Asumsi yang terpenting yang harus terpenuhi dalam regresi cox proportional hazard yaitu asumsi proporsional hazard. Pada penelitian ini menggunakan uji global test atau Goodness Of Fit (GOF) dengan uji statistik Chi-Square. Dari output didapatkan dapat dilihat pada tabel 4.

Tabel 4 Pengujian asumsi propotional hazard

\begin{tabular}{lc}
\hline Peubah & $p$-value \\
\hline Jenis Kelamin $\left(\mathrm{X}_{1}\right)$ & 0,98 \\
Usia $\left(\mathrm{X}_{2}\right)$ & 0,56 \\
Trombosit $(\mathrm{X} 3)$ & 0,32 \\
Leukosit $(\mathrm{X} 4)$ & 0,77 \\
\hline Hemoglobin $(\mathrm{X} 5)$ & 0,92 \\
Hematokrit $(\mathrm{X} 6)$ & 0,78
\end{tabular}




\begin{tabular}{lc}
\hline Peubah & $p$-value \\
\hline Suhu Badan $(\mathrm{X} 7)$ & 0,30 \\
\hline
\end{tabular}

Sumber: Hasil analisis data sekunder 2018

Dari hasil uji asumsi propotional hazard, menunjukkan bahwa hasil dari uji global test untuk setiap peubah masingmasing memiliki $p$-value $>0,05$. Adapun hipothesisnya yaitu:

$H_{0}$ : Data memenuhi asumsi PH

$H_{1}$ : Data tidak memenuhi asumsi PH

Penolakan $H_{0}$ jikap - value $<\alpha$ artinya data tidakmemenuhi asumsi PH

Jadi, dapat disimpulkan bahwa $\mathrm{H}_{0}$ diterima karena sebuah asumsi proportional hazard terpenuhi untuk semua peubahpeubah bebas yang digunakan.

\subsubsection{Estimasi Parameter dan Pengujian Parameter}

Parameter $\beta_{\mathrm{j}}$ pada model Cox merupakan parameter yang belum diketahui nilainya yang menggambarkan peluang bersama obsevasi data. Pada pendugaan ini digunakan metode maximum partial likelihood estimasi Breslow

Tabel 5 Tabel Estimasi Paramater Model Cox dengan metode Breslow

\begin{tabular}{cccc}
\hline Peubah & Koefisien & SE & p-value \\
\hline Jenis Kelamin $\left(\mathrm{X}_{1}\right)$ & $-0,1939$ & 0,3281 & 0,5546 \\
Usia $\left(\mathrm{X}_{2}\right)$ & $-0,0094$ & 0,0113 & 0,4029 \\
Trombosit $\left(\mathrm{X}_{3}\right)$ & $-0,0035$ & 0,0024 & 0,1357 \\
Leukosit $\left(\mathrm{X}_{4}\right)$ & 0,0974 & 0,0447 & 0,0295 \\
Hemoglobin $\left(\mathrm{X}_{5}\right)$ & $-0,2476$ & 0,1694 & 0,1438 \\
Hematokrit $\left(\mathrm{X}_{6}\right)$ & 0,1480 & 1,0602 & 0,0141 \\
Suhu badan $\left(\mathrm{X}_{7}\right)$ & $-0,0655$ & 0,1624 & 0,6864 \\
\hline
\end{tabular}

Sumber: Hasil analisis data sekunder 2018

Dari hasil estimasi parameter pada tabel 5 dengan menggunakan metode Breslow secara keseluruhan semua peubah memberikan kontribusi terhadap kesembuhan pasien penderita penyakit DBD (Y). Hasilnya adalah leukosit $\left(\mathrm{X}_{4}\right)$ dan hematokrit $\left(\mathrm{X}_{6}\right)$ yang signifikan tehadap model dan dapat memberikan kontribusi positif terhadap laju kesembuhan penyakit DBD. Maka model cox terbaik pada kejadian bersama adalah sebagai berikut :

$$
h(t, x)=h_{0}(t) \exp \left(0,0974 x_{4}+0,1480 x_{6}\right)
$$

\subsubsection{Hazard Ratio}

Untuk melihat laju kesembuhan pasien penderita penyakit DBD maka dapat dilihat dari nilai Hazard Ratio yang digunakan dengan mencari nilai ratio dari peubah-peubah yang dikategorikan sebagai model terbaik

Tabel 6 Nilai Hazard Ratio untuk Peubah Leukosit dan Hematokrit

\begin{tabular}{lcc}
\hline \multicolumn{1}{c}{ Peubah } & $\widehat{\boldsymbol{\beta}}$ & Hazard Ratio $\left(\boldsymbol{e}^{-\widehat{\boldsymbol{\beta}}}\right)$ \\
\hline Leukosit $\left(\mathrm{X}_{4}\right)$ & 0,0974 & 1,1024 \\
Hematokrit $\left(\mathrm{X}_{6}\right)$ & 0,1480 & 1,595 \\
\hline
\end{tabular}

Sumber: Hasil analisis data sekunder 2018

Nilai hazard ratio merupakan ukuran kegagalan yang digunakan untuk mengetahui tingkat risiko yang dapat dilihat dari perbandingan antara suatu individu. Hasil estimasi parameter dari peubah Leukosit sebesar 1,1024 menjelaskan laju kesembuhan pasien penderita penyakit $D B D$ dengan jumlah leukosit sebesar 1,1024 yang berarti (>1) yang artinya semakin tinggi jumlah leukosit seorang pasien, semakin lama pula kesembuhannya sama halnya untuk peubah Hematokrit sebesar 1,595 (>1) yang berarti bahwa semakin tinggi Hematokrit pasien penderita penyakit $D B D$ semakin lama pula kesembuhannya. 


\subsection{Pembahasan}

\subsubsection{Karakteristik Penelitian}

Penelitian ini menggunakan analisis survival dengan meggunakan 51 sampel. Dimana rata-rata lama perawatan berkisar antara 5 hari. Rata-rata umur pasien penderita DBD adalah 16 tahun. Berdasarkan hasil penelitian, Jenis kelamin penderita DBD dari periode Januari-Desember 2016 lebih banyak berjenis kelamin perempuan. Untuk kandungan trombosit pasien rata-rata $115.000 / \mu \mathrm{l}$. Sedangkan rata-rata untuk kadar leukosit sebesar $6.300 / \mathrm{mm}^{3}$. Untuk rata hemoglobin pada pasien penderita DBD adalah 13,3g/dl. Selanjutnya, rata-rata kadar hematokrit pada pasien penderita DBD adalah 40,1\%.dan untuk rata-rata suhu tubuh pada pasien penderita DBD adalah $37,6^{\circ} \mathrm{C}$.

\subsubsection{Model Cox PH Pada Kejadian Bersama dengan Metode Breslow}

Dalam analisis survival, seringkali ditemukan adanya suatu event dimana individu mengalami kejadian pada waktu yang bersamaan. Hal inilah yang disebut sebagai kejadian bersama (ties). Jika suatu data terdapat ties, khususnya pada model Cox $P H$ maka akan menimbulkan permasalahan dalam pembentukan partial likelihood atau dalam mengestimasi parameter yang berhubungan dengan penentuan anggota dari himpunan risiko. Permasalahan ini dapat diatasi dengan menggunakan metode Breslow. Dari data pasien penyakit DBD yang berjumlah 51 pasien terlihat bahwa jumlah pasien dengan jenis kelamin perempuan lebih banyak dibandingkan dengan laki-laki. Selanjutnya dalam pengujian distribusi menunjukkan nilai $p$-value pada data tidak mengikuti distribusi itu artinya, dilanjutkan dengan menggunakan model semiparametrik yaitu model Cox Proportional Hazard (Cox PH). Selanjutnya uji asumsi PH terlihat bahwa suatu asumsi proportional hazard terpenuhi untuk semua peubah bebas. Selanjutnya pendugaan parameter dengan menggunakan metode Breslow terlihat peubah-peubah yang signifikan terhadap model. Dan peubah yang signifikan yakni leukosit dan hematokrit, sedangkan peubah yang tidak signifikan yakni jenis kelamin, usia, trombosit, hemoglobin dan suhu badan yang nilai $p$-value nya $<\alpha$. Maka dari itu model Cox $P H$ adalah sebagai berikut :

$$
h(t, x)=h_{0}(t) \exp \left(0,0974 x_{4}+0,1480 x_{6}\right)
$$

\subsubsection{Faktor-faktor Yang Mempengaruhi Laju Kesembuhan Penyakit DBD}

Ada banyak faktor yang berkontribusi dalam mempengaruhi laju kesembuhan penyakit Demam Berdarah Dengue atau sering disebut dengan DBD. Pada penelitian ini faktor-faktor yang berpengaruh diantaranya peubah jenis kelamin, usia, trombosit, leukosit, hemoglobin, hematokrit, dan suhu badan. Dari hasil penelitian ini dijelaskan ada faktor yang signifikan mempengaruhi laju kesembuhan pasien penderita penyakit DBD dan ada pula beberapa faktor yang tidak signifikan dalam laju kesembuhan pasien. Adapun peubah yang signifikan dalam penelitian ini adalah leukosit dan hematokrit. Jumlah leukosit itu sendiri merupakan salah satu indikasi yang berperan dalam diagnosis DBD karena memiliki $p$-value $=0,097<\alpha 0,05$, dengan nilai hazard ratio sebesar 1,1024 , berarti lebih dari 1 yang artinya semakin tinggi jumlah leukosit seorang pasien, semakin lama pula kesembuhannya. Begitupun dengan hematokrit yang memiliki $p$-value $=0,0141<\alpha 0,05$, dengan nilai hazard ratio sebesar 1,595 yang juga berarti sama lebih dari 1 yang artinya semakin tinggi jumlah hematokrit seorang pasien, semakin lama pula kesembuhannya. Selain peubah yang berpengaruh, ada pula peubah yang tidak signifikan yaitu waktu, usia, trombosit, hemoglobin, dan suhu badan. Peubah-peubah tersebut tidaklah berpengaruh dikarenakan memiliki nilai $p$-value yang $>\alpha 0,05$.

\section{Kesimpulan}

Berdasarkan uraian hasil dan pembahasan maka dapat disimpulkan bahwa:

1) Model cox proportional hazard pada kejadian bersama (ties) data penderita penyakit DBD di RSAL Jala Ammari Makassar tahun 2016 adalah :

$$
h(t, x)=h_{0}(t) \exp \left(0,0974 x_{4}+0,1480 x_{6}\right)
$$

2) Faktor-faktor yang mempengaruhi laju kesembuhan pasien penderita DBD adalah kadar leukosit $\left(\mathrm{X}_{4}\right)$ dan hematokrit $\left(\mathrm{X}_{6}\right)$. 


\section{References}

Breslow, N. (1974). Covariance Analysis of Censored Survival Data. Biometrics 30 : $89-99$

Burden, R. L., \& Faires , j. D. (2001). Numerical Analysis Pasific Grove: Brooks/Cole.

Collect, D. (2003). Data in Medical Research Second Edition. New York: Chapman \& Hall.

Dahlan, M. S. (2013). Analisis Survival "Dasar-Dasar Teori dan Aplikasi Program Stata”. Sagung Seto: Jakarta

Hosmer. D.W., Lemeshow, S., \& Mya. S (2008). Applied Survival Analysis:Regression Modelling of Time to Event Data. New York.

Kleinbaum, D.G., \& Mitchel, K. (2005). Survival Analysis A Self-Learning Text. New York: Springer.

Kosasih, E.N dan A.S Kosasih. 2008. Tafsiran Hasil pemeriksaan Laboratorium Klinik edisi kedua. Karisma Publishing Group : Tangerang.

Jenkins, S.P. (2005). Survival Analysis. Unpublished Manuscrip. New York

Lawless, J. (2003). Statistical models and method for lifetime data (2nd ed.). New York: John Willey and Sons, Inc.

Lee, E., \& Wang, J. (2003). Statistical Methods for Survival Data Analysis (third edition). Canada: Wiley.

Nadjib Bustan, M., dkk. (2018). Cox Proportional Hazard Survival Analysis to Inpatient Breast Cancer Cases. Journal of physics: Conf.Series 1028.

Rahmadeni, \& Ranti, S. (2016). Perbandingan Model Regresi Cox Menggunakan Estimasi Parameter Efron Partial Likelihood dan Breslow Partial Likelihood. Seminar Nasional Teknologi Informasi, Komunikasi dan Industri (SNTIKI) 8 ,2085-9902.

Sadikin, M., 2008. Biokimia Darah, Widyamedika, Jakarta

Sucipto, P.T., Raharjo, M., \& Nurjazuli (2015). Faktor-Faktor Yang Mempengaruhi Kejadian Penyakit Demam Berdarah (DBD) Dan Jenis Serotipe Virus Dengue Di Kabupaten Semarang. Jurnal Kesehatan Lingkungan Vol.14 No.2.

Sutedjo, AY .2006. Mengenal Penyakit Melalui Pemeriksaan Laboratorium, Yogyakarta: Amara Books.

Therneau, T. M., \& Grambsch, P. M. (2000). Modeling Survival Data Extending The Cox Model. New York: Springer_Verlag.

Vitriana, A. N., \& Kusumawati, R. (2017). Model Cox Extended Untuk Mengatasi Nonproportional Hazard Pada Kejadian Bersama. AdMathEdu Vol.7 No.1 .

Xin, xin. (2011). A Study of Ties and Time Varying Covariate in Cox Proportional Hazard Model. Thesis The University of Guelph. 